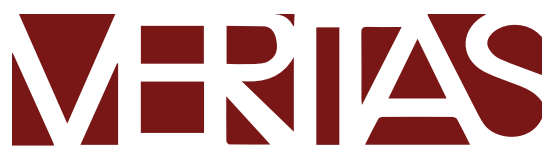

$\begin{array}{llllllllllll}P & O & R & T & O & A & L & E & G & R & E\end{array}$

d http://dx.doi.org/10.15448/1984-6746.2019.1.31597

\title{
ADAM SMITH E A VIRTUDE DA JUSTIÇA
}

Adam Smith and the Virtue of Justice

Adam Smith y la Virtud de la justicia

Denis Coitinho'

\section{Resumo}

O objetivo central desse artigo é refletir sobre o papel e o significado do critério de justiça no pensamento de Adam Smith, considerando especialmente a obra The Theory of Moral Sentiments e, parcialmente, as obras Lectures on Jurisprudence e An Inquiry into the Nature and Causes of the Wealth of Nations. O propósito básico é tentar esboçar uma teoria da justiça que pode ser encontrada nas obras de Smith, particularmente no seu texto de 1759, a saber, The Theory of Moral Sentiments. Para tal, inicio esclarecendo alguns conceitos centrais de sua teoria moral sentimentalista, a saber, empatia (sympathy), espectador imparcial (impartial espectator) e mão invisível (invisible hand). Posteriormente, investigo o papel das virtudes nesta teoria normativa anti-utilitarista e a distinção entre virtudes positivas e negativas. De posse disso, o próximo passo será analisar a concepção de justiça retributiva defendida por Smith, que parece defender uma teoria híbrida da punição por englobar aspectos retributivista, preventivista, expressivista e reabilitacionista. Por fim, reflito sobre o significado da justiça como virtude negativa e sua ligação com os direitos.

Palavras-chave: Virtudes. Punição. Justiça. Direito. Adam Smith.

\footnotetext{
Doutor em Filosofia pela Pontifícia Universidade Católica do Rio Grande do Sul. Professor do Programa de Pós-Graduação da Universidade do Vale do Rio dos Sinos (Unisinos), São Leopoldo, RS, Brasil. http://orcid.org/0000-0002-2592-5590.E-mail: deniscs@unisinos.br.
} 


\begin{abstract}
The central aim of this paper is to reflect on the role and meaning of the criterion of justice in Adam Smith's thought, especially considering The Theory of Moral Sentiments, and partially Lectures on Jurisprudence and An Inquiry into the Nature and Causes of the Wealth of Nations. The basic intention is to try to outline a theory of justice that we could find in the works of Smith, particularly in his work of the 1759, namely, The Theory of Moral Sentiments. To this end, I will begin by clarifying some central concepts of his sentimentalist moral theory, such as, sympathy, impartial spectator and invisible hand. Subsequently, I will investigate the role of virtues in this anti-utilitariam normative theory and the distinction between negative and positive virtues. Given this, the next step will be to examine Smith's conception of retributive justice, which seems to defend a hybrid theory of punishment by encompassing retributivist, consequentialist, expressivist, and rehabilitative aspects. Finally, I will reflect about the meaning of justice as a negative virtue and its connection with the law.
\end{abstract}

Keywords: Virtues. Punishment. Justice. Law. Adam Smith.

\title{
Resumen
}

El objetivo principal de este artículo es reflexionar sobre el papel y la importancia del criterio de justicia en el pensamiento de Adam Smith, considerando especialmente la obra The Theory of Moral Sentiments y parcialmente Lectures on Jurisprudence e An Inquiry into the Nature and Causes of the Wealth of Nations. El propósito básico es esbozar una teoría de la justicia que se puede encontrar en la obra de Smith, particularmente en el texto de 1759, es decir, The Theory of Moral Sentiments. Para ello, empezo clarificando algunos conceptos centrales de su teoría moral sentimientalita, es decir, empatía (sympathy), espectador imparcial (impartial espectator) y la mano invisible invisível (invisible hand). Después, investigo el papel de las virtudes en estateoría normativa anti-utilitarista y la distinción entre virtudes positivas y negativas. Tomando esto como punto de partida, el siguiente paso será analizar el concepto de justicia retributiva propugnada por Smith, la que parece defender una teoría híbrida del castigo por englobar aspectos retributivista preventivista, expressivista y reabilitacionista. Por último, busco reflexionar sobre el significado de la justicia como virtud negativa y su conexión con los derechos.

Palabras clave: Virtudes. Castigo. Justicia. Ley. Adam Smith. 


\section{Introdução}

Seria possível contar com uma teoria moral que tomasse como base os sentimentos de ressentimento e gratidão como critérios normativos para a reprovação e aprovação de uma ação, respectivamente considerando a empatia como princípio fundamental da moral, mas, que, por outro lado, também levasse em consideração as regras gerais (princípios) com a finalidade de sanar as limitações espaciais das emoções? Seria desejável fazer uso de uma teoria normativa antiutilitarista, por não identificar a única motivação do agente como sendo o autointeresse, mas que também levasse à sério as consequências das ações, utilizando uma perspectiva de segunda pessoa, preferencialmente a terceira e, também, que levasse em conta seriamente o método empírico e a linguagem tanto das virtudes como dos direitos? De forma similar, não seria atraente poder contar com uma teoria da justiça que distinguisse claramente entre virtudes positivas e negativas, localizando tanto a política como o direito no âmbito da moralidade pública, mas sem deixar de chamar atenção para a importância da moralidade privada, inclusive para a economia? E, ainda, não seria mais eficiente utilizar uma teoria da justiça que justificasse a punição com o uso de critérios variados, tais como o retributivista, preventivista, expressivista e reabilitacionista e, também, que garantisse os direitos individuais dos agentes, tais como a vida, integridade, propriedade, além de ter por foco a estabilidade social?

Além de ser desejável, penso que seria tanto atraente quanto mais eficiente poder contar com uma teoria moral nesses moldes descritos acima, a fim de poder lidar com os complexos problemas morais e políticos que surgem a todo momento. Além do mais, isso parece possível, uma vez que a teoria moral apresentada por Adam Smith na obra The Theory of Moral Sentiments, por exemplo, mostra possuir essas características listadas. É fato que Adam Smith é mais conhecido como um pensador que refletiu sobre 
os problemas da economia, sendo a sua obra The Wealth of Nations ${ }^{2}$ um dos textos mais conhecidos e citados não apenas na área econômica. Por outro lado, a sua obra moral, que foi escrita dezessete anos antes, parece não ter merecido ainda toda a atenção que lhe é devida, com exceção para o estudo devotado ao conceito de sympathy e a distinção identificada entre Hume e Smith. No entanto, a respeito de que tipo de teoria sentimentalista Smith estaria usando, bem como que tipo de teoria da justiça estaria sendo defendida por esse importante representante do iluminismo escocês, a atenção interpretativa ainda se mostra muito limitada.

Dito isso, um dos objetivos desse artigo, então, será tentar mostrar o engenho normativo da teoria moral apresentada por Smith, procurando destacar sua estratégia de normatividade indireta, bem como ressaltar a conexão entre e a linguagem das virtudes e dos direitos, assim como defender o ganho de podermos contar com uma teoria tão atraente como esta que parece lidar muito bem com problemas complexos como o da justificação da punição, relação entre deveres e direitos, equidade, sorte moral, segurança jurídica, entre outros, de forma a se mostrar como mais eficiente do que as teorias alternativas, tais como a utilitarista ou a racionalista. Um objetivo adicional será o de tentar identificar os termos elementares de uma teoria da justiça que parece congregar coerentemente aspectos liberais e comunitaristas.

No restante do texto, procurarei esclarecer, inicialmente, os conceitos-chave da teoria dos sentimentos morais de Adam Smith, a saber, os conceitos de empatia (sympathy), de espectador imparcial (impartial spectator) e de mão invisível (invisible hand), além de procurar detalhar o método indutivista usado. Posteriormente, refletirei sobre a importância

\footnotetext{
2 As obras de Smith serão abreviadas da seguinte maneira: An Inquiry into the Nature and Causes of the Wealth of Nations (WN), Lectures on Jurisprudence ( $L J)$, The Theory of Moral Sentiments (TMS). As referências da TMS serão dadas indicando em sequência a parte da obra, a seção, o capítulo e o parágrafo. Ex: TMS, l.i.1.1. As referências da $W N$ serão dadas indicando em sequência o livro, o capítulo e o parágrafo. Ex: $W N$, I.i.1. As referências da $L J$ serão dadas indicando as lições de 1762-3 (A) e as de 1766 (B), seguindo-se da data e parágrafo. Ex: LJ(A), i.9.
} 
das virtudes nessa teoria normativa, ressaltando a distinção entre as virtudes positivas da benevolência (benevolence), da prudência (prudence) e do autodomínio (self-command) e a virtude negativa da justiça (justice). Por fim, investigarei sobre uma possível teoria da justiça smithiana que pode ser identificada. Inicialmente, o foco recairá na justiça retributiva híbrida, por justificar a punição apelando para vários critérios, a saber, retributivista, preventivista, expressivista e reabilitacionista. Após, investigarei sobre a concepção de justiça entendida tanto como uma virtude moral (negativa) quanto no âmbito dos direitos individuais, tais como vida, integridade, liberdade, propriedade, entre outros,

\section{Empatia e espectador imparcial}

A despeito de certa imagem equivocada do pensamento smithiano, propiciada, talvez, por uma limitação interpretativa da parte da $W N$ que diz que não seria da benevolência do açougueiro, do cervejeiro e do padeiro que se esperaria o jantar, mas sim do seu autointeresse, apelando não para a sua humanidade, mas ao seu amor-próprio (WN I.ii.3), a TMS inicia com a constatação de que por mais egoístas que os indivíduos sejam, eles têm um interesse natural tanto pela felicidade como pelo infortúnio dos outros. Em suas palavras:

Por mais egoísta que se imagine o homem, é óbvio que há alguns princípios em sua natureza que o fazem interessar-se pela sorte dos outros, e considerar a felicidade deles necessária para si mesmo, embora nada extraia disso senão o prazer de assistir a ela. Dessa espécie é a piedade, ou compaixão, emoção que sentimos ante a desgraça dos outros, quer quando a vemos, quer quando somos levados a imaginá-la de modo muito vivo. É fato óbvio demais para precisar ser comprovado que frequentemente ficamos tristes com a tristeza alheia. (...) O maior rufião, 
o maior infrator das leis da sociedade, não é desprovido desse sentimento (TMS, I.i.1.1). ${ }^{3}$

Ao invés de afirmar o autointeresse e o amor-próprio como as únicas motivações egoístas do agente, o que Smith parece estar defendendo é que, como membros de uma comunidade moral e política, os agentes possuem emoções morais que os fazem levar em conta tanto a felicidade como a infelicidade dos outros, o que implica considerar a empatia (sympathy) como uma capacidade do agente de se imaginar no lugar do outro, e tomar os sentimentos de ressentimento e gratidão como critérios centrais da desaprovação ou aprovação da ação, isto é, como critério da conveniência (propriety) da ação, com acréscimos das regras gerais para corrigir a inconveniência das emoções momentâneas (TMS, I.i.3.4). No entanto, antes de detalhar o modelo normativo que está sendo defendido, é importante chamar atenção para a metodologia empregada.

Como representante do iluminismo escocês, Smith buscou utilizar a metodologia das ciências naturais aplicada às ciências humanas e sociais em razão da preocupação com o progresso social e o desenvolvimento da economia política. Adotou o método científico indutivista, tal qual Newton, que procurou descrever os fenômenos físicos e identificar suas leis ordenadoras como a lei da inércia, dinâmica, lei da ação e reação e a lei da gravitação universal. No caso moral, partiu de uma descrição do fenômeno moral e, a contar dessa descrição de censura e elogio que endereçamos aos outros e a nós mesmos pelos sentimentos de ressentimento e gratidão que as ações e caráter do agente geram em nós, procurou

\footnotetext{
3 TMS, I.i.1.1: How selfish soever man may be supposed, there are evidently some principles in his nature, which interest him in the fortune of others, and render their happiness necessary to him, though he derives nothing from it except the pleasure of seeing it. Of this kind is pity or compassion, the emotion which we feel for the misery of others, when we either see it, or are made to conceive it in a very lively manner. That we often derive sorrow from the sorrow of others, is a matter of fact too obvious to require any instances to prove it. (...) The greatest ruffian, the most hardened violator of the laws of society, is not altogether without it.
} 
identificar sua lei reguladora, que seria o princípio da empatia (sympathy) ou do espectador imparcial (impartial spectator). ${ }^{4}$

Esse princípio da empatia, importante para os iluministas escoceses, tais como Hume, Hutcheson e o próprio Smith, contrapõe-se tanto ao racionalismo quanto ao egoísmo moral, uma vez que sintetiza uma ideia básica de que as pessoas seriam motivadas, para além de seu próprio interesse e amor-próprio, pelo sentimento compartilhado com os outros, isto é, como uma capacidade imaginativa de se colocar no lugar do outro. Não se pode sentir as emoções de ressentimento e gratidão dos outros agentes, mas é possível imaginar como se sentiria ao se estar no lugar das outras pessoas que sentem ressentimento, por exemplo, por terem sido enganadas ou mesmo roubadas. A empatia não é propriamente uma paixão, como considerada por Hume, mas, antes, uma correspondência de sentimentos, sendo melhor compreendida como um ato de imaginação, como um ato de solidariedade com qualquer paixão (TMS, I.i.1.5). ${ }^{5}$

Veja-se que essa maneira de compreender o fenômeno moral a partir das atitudes reativas às ações e mesmo ao caráter do agente, já revela uma importante consideração, a saber, que os juízos morais seriam realizados em uma perspectiva de segunda pessoa, preferencialmente a uma perspectiva de primeira ou mesmo terceira pessoa. Isso parece ficar claro a partir do importante papel desempenhado pela figura idealizada do espectador imparcial (impartial espectator) na filosofia moral

\footnotetext{
4 Como iluminista, além de defensor do liberalismo, Smith via o sectarismo e o fanatismo como corruptores dos sentimentos morais, e a ciência e a filosofia como "o grande antídoto do veneno do entusiasmo e superstição" (WN, V.i.g.14). Sobre a influência do iluminismo escocês no pensamento de Adam Smith, ver CERQUEIRA, 2006, p. 10-24. E sobre as bases de sua filosofia moral, ver, também, CERQUEIRA, 2008, p. 71-82.

5 Alexander Broadie observa que o conceito de sympathy de Smith implica na capacidade imaginativa de se colocar no lugar do outro e sentir as emoções (imaginando) de gratidão e ressentimento por meio de um espectador imparcial. Isto parece estar relacionado com um tipo de universalidade no processo de abstração do espectador, não sendo um puro sentir as emoções alheias e, também, parece estar ligado a um tipo de naturalismo, uma vez que haveria uma base naturalista para o espectador imparcial chegar aos juízos morais com base no conjunto de sentimentos que são compartilhados pela comunidade moral. Ver BROADIE, 2006, p. 163-170; 186-187.
} 
de Adam Smith. Para saber se dada ação seria certa ou errada, deve-se contar com a aprovação de um espectador com capacidade imaginativa para identificar os sentimentos de gratidão e ressentimento nos outros, sentimentos que serão a base normativa para aprovação ou desaprovação da ação. Nas palavras de Smith:

\begin{abstract}
Em todos esses casos, para que haja alguma correspondência de sentimentos entre o espectador e a pessoa envolvida, o espectador deve, em primeiro lugar, esforçar-se tanto quanto possível para colocar-se na situação do outro, e tornar sua cada pequena circunstância de aborrecimento que provavelmente ocorra ao sofredor. Deve adotar integralmente o caso do seu companheiro com os mínimos incidentes; e empenhar-se por interpretar de maneira mais perfeita possível a mudança imaginária da situação sobre a qual sua empatia é fundada (TMS, I.i.4.6)
\end{abstract}

Esse experimento mental de se colocar no lugar do outro parece ter por base uma capacidade autorreflexiva do agente, de forma a avaliar a própria situação por meio do julgamento dos outros, como um ato de imaginação para identificar como os outros avaliariam esses atos, de modo a poder ajustar o próprio comportamento. Assim, o espectador imparcial seria o "homem dentro do peito", o "grande juiz e árbitro" da conveniência da ação (TMS, III.2.32), que tem a capacidade de não apenas aprovar o comportamento dos outros, mas se ver como pessoa e membro da comunidade moral por meio da empatia com as outras pessoas, o que traz por consequência uma capacidade de avaliar de forma imparcial ou, ao menos com reciprocidade,

\footnotetext{
6 TMS, I.i.4.6: In all such cases, that there may be some correspondence of sentiments between the spectator and the person principally concerned, the spectator must, first of all, endeavour, as much as he can, to put himself in the situation of the other, and to bring home to himself every little circumstance of distress which can possibly occur to the sufferer. He must adopt the whole case of his companion with all its minutes incidents; and strive to render as perfect as possible, that imaginary change of situation upon which his sympathy is founded.
} 
a conduta e a motivação humana. Parece poder representar as atitudes sociais estabelecidas, isto significando ser a própria voz da sociedade.?

O ponto que gostaria de ressaltar é que esta teoria sentimentalista como proposta por Smith parece ter por base o estabelecimento de um processo de ajuste mútuo mediante uma busca empática para o estabelecimento de um ponto de vista moral comum. Isso já parece revelar que as obrigações morais dos agentes não poderiam ser tomadas como um critério normativo direto, como algo existente na natureza ou que poderia ser intuído pela razão humana. Ao contrário, essas obrigações de ser justo, benevolente, prudente e ter autodomínio, por exemplo, como se verá a seguir, só poderiam ser compreendidas em uma perspectiva de segunda pessoa, de forma que os membros de uma comunidade fariam certas exigências a partir dos sentimentos de ressentimento ou gratidão e seriam essas exigências a base normativa dos deveres. Não se estaria no domínio da normatividade direta, como seria o caso de uma perspectiva de terceira pessoa, puramente objetiva, ou mesmo de primeira pessoa, puramente subjetiva. Ao contrário, este modelo normativo indireto teria por base a intersubjetividade ou a interpessoalidade, de forma a tomar o ponto de vista social como o verdadeiro ponto de vista moral e político ${ }^{8}$

\footnotetext{
7 A respeito do conceito de espectador imparcial, Haakonssen observa que ele representaria o ato último de criatividade imaginativa ou a etapa mais elevada de nosso desenvolvimento moral. Não significaria possuir um conhecimento absoluto do que deve ser feito em cada situação. Antes, esta capacidade de imparcialidade serviria para explicar como as pessoas fazem juízos morais de mérito ou demérito sobre o comportamento e motivação dos agentes, sugerindo que isto ocorre por uma invocação implícita de sua noção de conveniência ideal. (Ver HAAKONSSEN, 2006, p. 14-15).

8 Essa teoria moral sentimentalista de Smith parece similar à proposta feita por Stephen Darwall em The Second-Person Standpoint, de forma a considerar a moralidade a partir de uma perspectiva de segunda pessoa. Para Darwall, os conceitos morais de obrigação, certo e errado, direitos, etc. possuem uma estrutura irredutível em segunda pessoa, de forma a tomar o outro como exigindo de alguém o cumprimento de certo dever. $E$, assim, as obrigações morais seriam bipolares, uma vez que existiria o agente que é obrigado, por um lado, e o grupo a quem ele é obrigado, por outro. Inclusive, Darwall faz referência no capítulo "Empathy and Adam Simth on Exchange" que Adam Smith seria um dos primeiros filósofos a fazer uso do ponto de vista em segunda pessoa para pensar a moralidade. (Ver DARWALL, 2006, p. 43-48).
} 
Esse padrão normativo social, então, teria a capacidade de, inclusive, corrigir as falsas representações do amor de si dos agentes (TMS, III.3.4). E isso parece implicar que a vida em sociedade é a condição natural para o ser humano; a tarefa central da ética seria demostrar empiricamente as regularidades da vida social. E a partir dessas regularidades de se seguir regras coletivamente, por exemplo, se estabeleceria o critério para o agente saber sobre os seus deveres morais. Importante notar que a sociabilidade para Smith não é o resultado de um cálculo racional ou mesmo o resultado de um contrato. Antes, ela é uma condição natural dos agentes. $E$, sendo assim, a moralidade seria tomada como um artifício, que é uma condição natural da sociabilidade humana, sendo a sociedade um tipo de espelho ao agente:

Se fosse possível que uma criatura humana vivesse em algum lugar solitário até alcançar a idade madura, sem qualquer comunicação com sua própria espécie, não poderia pensar em seu próprio caráter, a conveniência ou demérito de seus próprios sentimentos e conduta, a beleza e deformidade de seu próprio rosto. Todos esses são objetos que não pode facilmente ver, para os quais naturalmente não olha, e com relação aos quais carece de espelho que sirva para apresentá-los à sua visão. Tragam-no para a sociedade e será imediatamente provido do espelho que carecia (TMS, III.1.3) 9 .

Como visto pela citação acima, o padrão normativo que está sendo defendido para avaliar tanto o caráter dos indivíduos bem como o mérito ou demérito dos sentimentos e ações dos agentes é aquilo que seria tomado como conveniente pela própria comunidade moral. Em outras palavras,

\footnotetext{
9 TMS III.1.3: Were it possible that human creature could grow up to manhood in some solitary place, without any communication with his own species, he could no more think of his own character, of the propriety or demerit of his own sentiments and conduct, of the beauty or deformity of his own face. All these are objects which he cannot easily see, which naturally he does not look at, and with regard to which he is provided with no mirror which can present them to his view. Bring him into society, and he is immediately provided with the mirror which he wanted before.
} 
a sociedade forneceria a regra para a avaliação das paixões e ações dos sujeitos, e também das consequências dessas ações. A conclusão até aqui parece ser a constatação de que a regra moral não é privada para Smith, uma vez que tanto a censura como o elogio seriam coletivos, isto é, seriam consideradas atitudes reativas. Por isso, só se poderia adquirir virtudes pela crítica social. ${ }^{10}$ Mas, se investigará esse ponto a seguir.

\section{O papel das virtudes}

Após analisar a importância das categorias de empatia e espectador imparcial na teoria moral de Adam Smith, o próximo passo será investigar o destacado papel que as virtudes desempenham nesse modelo normativo sentimentalista antiutilitarista. Na Parte VII da TMS, intitulada "Dos sistemas de filosofia moral", Smith examina os limites das principais teorias morais conhecidas pela tradição, defendendo uma conexão das virtudes da prudência, benevolência, justiça e autodomínio para a felicidade pessoal e coletiva, bem como defendendo o sentimento (empatia) como o princípio de aprovação da conduta. Os limites dessas teorias tradicionais, como a platônica, a aristotélica a estoica, a epicurista ou mesmo a de Hutcheson e Hume, por exemplo, poderiam ser explicados em razão da forma parcial e imperfeita com que realizaram a descrição da natureza humana e social. Para Smith:

Talvez todo sistema de moralidade que gozou de alguma reputação no mundo derive fundamentalmente de um ou outro dos princípios que venho tratando de revelar. Como nesse aspecto todos se fundam sobre princípios naturais, estão todos corretos

\footnotetext{
10 No influente artigo "Freedom and Resentment", Strawson argumenta que as atitudes reativas de ressentimento e gratidão, bem como atitudes autorreativas como culpa e atitudes vicárias como indignação seriam a base natural da responsabilidade moral, uma vez que mesmo o reconhecimento da verdade da tese determinista não iria impactar em nossa atribuição de liberdade aos agentes, de forma que haveria liberdade porque nos veríamos como responsáveis. De forma similar ao que podemos encontrar na Parte I da TMS, Strawson também procura descrever a moralidade em um âmbito interpessoal dos sentimentos morais. (Ver STRAWSON, 2008, p. 7-27).
} 
em certa medida. Porém, como muitos deles derivam de uma visão parcial e imperfeita da natureza, há também muitos erros em alguns aspectos (TMS, VII.i.1)."

Dada a constatação da limitação descritiva das teorias tradicionais, o próximo passo será observar que existem duas questões centrais que devem ser tratadas pela filosofia moral, a saber, a questão da natureza da virtude e o princípio de aprovação da conduta. Na segunda seção da Parte VII da TMS, Smith analisa as principais respostas que foram dadas à questão sobre a natureza da virtude. Inicia considerando as teorias que explicaram a natureza da virtude como o conveniente governo e direção de nossos afetos, estando a virtude na conveniência (propriety), tendo como seus exemplos centrais Platão, Aristóteles e os estoicos, especialmente Zenão. Após, examina a filosofia epicurista, que considera que a virtude estaria na prudência (prudence), isto é, a virtude consistiria apenas na busca de nosso interesse e felicidade particulares. Por fim, analisa a posição de Hutcheson, especialmente, o qual defende que a virtude estaria na benevolência (benevolence), isto é, que a virtude estaria nos afetos que visam a felicidade dos outros (TMS, VII.ii.1-3). ${ }^{12}$

Após a investigação sobre as várias respostas dadas ao problema da natureza da virtude, Smith examinará, na terceira seção da TMS VII, as respostas dadas à questão sobre o que deve contar como o princípio de aprovação da conduta dos agentes. Rejeitará os argumentos egoístas de Hobbes, Mandeville e Pufendorf, que tomam o amor-de-si (self-love) como

"TMS, VII.i.1: From some one or other of those principles which I have been endeavouring to unfold, every system of morality that ever had any reputation in the world has, perhaps, ultimately been derived. As they are all of them, in this respect, founded upon natural principles, they are all of them in some measure in the right. But as many of them are derived from a partial and imperfect view of nature, there are many of them too in some respects in the wrong.

12 Importante ressaltar a observação de Smith em relação ao ponto comum de todas essas teorias morais. Elas estabelecem uma distinção essencial entre virtude e vício, encorajando o que seria elogiável por ser valoroso e desencorajando toda disposição censurável. Diferente da posição defendida por Mandeville na Fábula das abelhas, que toma os vícios privados como garantia dos benefícios públicos. Para Smith, ao contrário, as virtudes públicas devem estar em coerência com as virtudes privadas. Ver TMS, VII.ii.4. 
o único princípio de aprovação da conduta e motivação dos agentes. De forma similar, rejeitará a posição racionalista de Cudworth apresentada no Treatise Concerning Eternal and Immutable Morality, que toma a razão (reason) como princípio de aprovação absoluto, uma vez que defenderá que as percepções sobre o certo e o errado se fundam no sentimento (sentiment), não como uma intuição ou percepção peculiar, tal como defendida por Hutcheson, mas com base na própria empatia (sympathy). ${ }^{3}$

O ponto central que quero chamar atenção é que a concepção de virtudes de Smith parece inclusivista, e, não, excludente. Ele não nega a importância das virtudes da prudência (prudence), da justiça (justice), da benevolência (benevolence) ou mesmo do autodomínio (self-command). O principal problema das teorias tradicionais foi não ter percebido que é necessário exercitar um conjunto de virtudes diferentes para se alcançar a felicidade tanto pessoal como social. ${ }^{14}$ Por exemplo, no domínio econômico, a virtude da prudência se mostra como essencial para possibilitar a identificação dos meios necessários ao fim da subsistência. Já no domínio moral, será a virtude da benevolência que terá um papel central por visar o bem dos outros de forma desinteressada ou superrogatória. Por sua vez, no âmbito jurídico e político, a justiça se mostrará como a virtude essencial para garantir o bem comum, além da probidade e liderança, por exemplo. Já a virtude do autodomínio, será tomada como uma metavirtude, isto

13 Esclarece que mesmo tomando o sentimento como o princípio de aprovação, não concordará com o modelo defendido por Hume, que considera a virtude residindo na utilidade, de forma a atribuir "o prazer com que o espectador examina a utilidade de qualquer qualidade à empatia pela felicidade dos que por ela são afetados" (TMS, VII.iii.3.17).

14 Importante acrescentar que a felicidade verdadeira, ao estilo do estoicismo, seria encontrada, para além de uma vida virtuosa, com a tranquilidade da alma diante dos diversos problemas. Também, que a sociedade deve contar com o desígnio divino para alcançar o bem comum. Este é o significado do conceito de mão invisível (invisible hand). Na única passagem da TSM em que o termo "mão invisível" é usado, ele tem o significado de mão de Deus ou desígnio da Providência. A passagem diz que os ricos são naturalmente egoístas, pensando apenas em sua própria comodidade. Mas, apesar disso, dividem com os pobres o produto de todas as suas melhorias, o que é do interesse social, sendo conduzidos por uma mão invisível, que significa o mesmo que a intenção da Providência. Ver TMS, IV.1.10. Sobre esse conceito, ver o artigo de BIANCHI; SANTOS, 2007, p. 635-662. 
é, como uma condição de possibilidade para as demais virtudes. Outra característica importante nessa concepção de virtudes é que o agente moral será tomado tanto como o que bem delibera particularmente como aquele que segue as regras gerais ou deveres. ${ }^{15}$

É interessante notar que Smith parece usar a linguagem das virtudes de forma conciliatória com a linguagem dos deveres. É no mínimo inusitado e inusual, para aqueles que foram influenciados de alguma maneira pelo texto de Anscombe ${ }^{16}$, imaginar uma teoria moral moderna que tome como intercambiáveis os conceitos de virtudes com o de deveres. Mas é exatamente isso que se encontra na teoria dos sentimentos morais de Smith. Veja-se a seção IV da parte VII da TMS, em que ele estabelece uma distinção entre as regras da justiça, que seriam precisas e acuradas como as regras da gramática e as regras de todas as outras virtudes, tomadas como imprecisas, vagas e indeterminadas. Aqui ele levanta a questão de qual seria o fundamento de toda obrigação (obligation) a partir de exemplo simples: um bandido obriga um viajante, sob ameaça de morte, a prometer-lhe certa quantia de dinheiro. O ponto central seria o de saber se o viajante estaria ou não obrigado a cumprir sua promessa (TMS, VII.iv.9).

De acordo com a jurisprudência (jurisprudence), por exemplo, o ato de extorsão do assaltante seria um crime que mereceria punição, o que anularia todo o direito de tal criminoso reivindicar o dinheiro prometido. Por outro lado, do ponto de vista da casuística (casuistry), a questão já não seria tão simples, uma vez que, independente da extorsão cometida,

15 Shaver observa corretamente que a teoria moral de Adam Smith é atraente por evitar duas caricaturas familiares, a saber, a do agente virtuoso aristotélico, que delibera corretamente sem fazer uso de regras ou deveres universais, e a do agente virtuoso kantiano, que toma como critério da ação as regras e deveres e não o seu sentimento frente ao caso. Diz que Smith toma o caráter do agente como a fonte normativa da avaliação moral, mas sem esquecer da importância dos conceitos deônticos como os deveres. (Ver SHAVER, 2006, p. 208).

16 Em Modern Moral Philosophy, de 1958, Elisabeth Anscombe considera que se deveria abandonar a linguagem moral dos deveres e se passar a usar a linguagem das virtudes, e isto porque a filosofia moral moderna passou a usar os conceitos de dever, correto e direitos sem mais apelar à ideia do legislador divino, além dela ser puramente prescritiva e, assim, essa linguagem teria perdido toda a sua força normativa. A vantagem do modelo das virtudes estaria na sua capacidade descritiva além da prescritiva. (Ver ANSCOMBE, 1998, p. 26-44). 
um agente virtuoso deveria sempre se pautar pela regra da justiça de observância de todas as promessas celebradas. Smith resolverá a questão apelando para os sentimentos comuns da humanidade, de forma que julgará como certo respeitar até mesmo uma promessa feita sob extorsão, "embora seja impossível determinar, por qualquer regra geral, em que medida isso se aplicaria a todos os casos, sem exceção" (TMS, VII.iv.12).

A engenhosa solução de Smith considerará a quantidade de dinheiro envolvida na promessa, e se o cumprimento dessa obrigação não traria por consequência o desrespeito a deveres mais importantes. Por exemplo, se uma pessoa prometesse cinco libras a um bandido e não as entregasse, ela incorreria em alguma censura, uma vez que a violação de qualquer promessa parece envolver algum tipo de desonra. Por outro lado, se a soma prometida fosse muito elevada, por exemplo, cem mil libras, e isso arruinasse a família do extorquido, então seria criminoso fazê-lo (TMS, VII.iv.12). Note-se que essa solução parece tomar o dever como relacionado ao bom senso, isto é, ao que se pode considerar o que se deva em relação a si mesmo e aos outros, o que é similar ao que se toma como um ato virtuoso, e isso porque essa obrigação seria variável pelo caráter, pelas circunstâncias, pela solenidade da promessa e pelos incidentes envolvidos no confronto, por exemplo. E, assim, Smith conclui que "a conveniência exata exigiria a observância de todas as promessas, sempre que elas não fossem inconsistentes com alguns outros deveres mais sagrados", como o respeito ao interesse público e o cuidado aos familiares, por exemplo (TMS, VII.iv.12). ${ }^{17}$

Após essa observação da conciliação entre a linguagem das virtudes e dos deveres na teoria moral de Smith, gostaria de esclarecer em maior

\footnotetext{
17 A regra que está sendo formulada parece ser a seguinte: tem-se o dever moral de cumprir a promessa (ou fazer certa ação) desde que esse ato não seja inconsistente com os deveres mais sagrados, isto é, mais valorosos. Essa regra parece conciliar harmonicamente uma teoria dos deveres com uma teoria das virtudes, uma vez que a determinação dos deveres não se daria por alguma regra fixa, absoluta, mas faria uso dos sentimentos e das emoções para saber o ponto certo em que se faria justiça. Nas palavras de Smith: "No que diz respeito a todas essas questões, o que num caso seria bom talvez não fosse em outro, e o que constitui a conveniência e felicidade de comportamento varia em cada caso, conforme a menor mudança da situação" (TMS, VII.iv.33).
} 
detalhe o que seria a "virtude" e quais virtudes seriam fundamentais para uma vida bem-sucedida nessa proposta e, sobretudo, apontar para a distinção entre as virtudes positivas e negativas. Isso será importante para se compreender a especificidade da justiça. Para Smith, a virtude é um traço de caráter regular que é elogiável pelos membros da comunidade em razão dele possibilitar a felicidade. Assim, a virtude é "a excelência, algo excepcionalmente grande e belo, que se revela muito acima do que é vulgar" (TMS, I.i.5.6). E, similarmente a Aristóteles, a medida da virtude é a mediania, isto é, nem o excesso e nem a deficiência (TMS, I.ii.1). Também, em consonância com a tradição clássica, considera todas as virtudes como artificiais, tanto a virtude da justiça quanto as virtudes da probidade, generosidade, prudência e franqueza. Mais importante ainda, é que o processo de aquisição das virtudes se daria pelo hábito, uma vez que seguir as regras (dos deveres ou das virtudes), por exemplo, seria satisfatório porque aprovado pelo espectador imparcial, sendo a repetição a maneira de formar o caráter virtuoso (TMS III.2.5).

Agora, quais virtudes seriam necessárias para garantir uma vida bem-sucedida para os agentes e a sociedade? Na Parte VI da TMS, que só apareceu na sexta e última edição de 1790, Smith trata do caráter da virtude, examinando tanto o caráter do indivíduo na medida em que afeta a sua própria felicidade e uma vez que pode afetar a felicidade das outras pessoas. Nessa parte, ele observa que a prudência é necessária na busca da felicidade pessoal, bem como se precisa tanto da justiça como da benevolência na busca da felicidade dos outros, sendo a justiça o que impede o prejuízo de outros e, a benevolência, o que impele a ajudá-los. Além dessas virtudes, o autodomínio é tomado como a própria medida da conveniência, sendo considerada a virtude mais importante no controle das paixões (TMS, VI.concl.1-2). Creio que não se cometeria nenhuma injustiça ao dizer que essa teoria parece conectar harmonicamente a virtude aristotélica da prudência com a virtude cristã da benevolência e mais a virtude estoica do autodomínio, além de incluir uma importante concepção moderna de justiça, de forma a considerá-la como uma virtude 
negativa ou como um dever perfeito em razão de se constituir a partir dos direitos reconhecidos dos agentes de certa comunidade..$^{18}$

Um último comentário sobre a distinção entre as virtudes positivas e negativas. Por mais que seja desejável e elogiável um comportamento virtuoso do ponto de vista privado, apenas a virtude da justiça será alvo da exigência pública. Nas palavras de Smith:

E sobre isso fundamenta-se a notável distinção entre a justiça e todas as outras virtudes sociais, em que ultimamente insistiu particularmente um autor de grande e original genialidade, a saber: que sentimo-nos sob uma estrita obrigação de agir de acordo com a justiça, do que segundo o que é agradável à amizade, caridade ou generosidade; que as práticas das virtudes recém-mencionadas parecem ter sido deixadas em certa medida à nossa própria escolha, mas que, de um modo ou outro, sentimo-nos de uma maneira peculiar atados, forçados e obrigados ao respeito à justiça (TMS, II.ii.1.5).19

Isso parece implicar uma concepção liberal de justiça, de forma a estipular a neutralidade ética do Estado, uma vez que os atos de generosidade, amizade ou caridade serão uma questão de escolha pessoal. Por exemplo, a benevolência é uma virtude voluntária e desinteressada. Sua ausência não é objeto de censura legal, apenas de desgosto. A justiça, por outro lado, impede de se ferir os vizinhos, implicando abstenção de

18 Raphael e Macfie, em sua introdução à TMS, dizem acertadamente que a teoria das virtudes defendida por Adam Smith é uma combinação das virtudes estoica e cristã, sendo uma combinação da filosofia estoica, que vê o autodomínio como central, com a filosofia de Hutcheson, que toma a benevolência como a virtude mais importante ao agente. Também, fazem referência à influência de Lord Kames na distinção realizada entre justiça e benevolência. (Ver RAPHAEL; MACFIE, 1976, p. 5-15).

19 TMS, II.ii.1.5: And upon this is founded that remarkable distinction between justice and all the other social virtues, which has of late been particularly insisted upon by an author of very great and original genius, that we feel ourselves to be under a stricter obligation to act according to justice, than agreeably to friendship, charity, or generosity; that the practice of these last mentioned virtues seems to be left in some measure to our own choice, but that, somehow or other, we feel ourselves to be in a peculiar manner tied, bound, and obliged to the observation of justice. 
se violar os direitos das pessoas, tais como o direito à vida, propriedade ou reputação. É por isso que apenas o seu não cumprimento é que será objeto de punição (TMS, II.ii.1.9). Contudo, tematizarei isso a seguir, a partir da análise da concepção de justiça retributiva defendida por Smith.

\section{Justiça retributiva}

Para que se possa melhor compreender a complexa concepção de justiça retributiva (teoria da punição) defendida por Smith, é importante iniciar ressaltando que ele parece defender uma posição liberal em contraposição ao paternalismo e moralismo jurídico forte. E isso em razão da observância das regras da justiça, como virtude negativa, não se ligar à vontade do agente, podendo ser exigida pela força. Assim, a violação dessas regras exporia o ofensor ao ressentimento do espectador imparcial e à consequente punição. Isso parece implicar na consideração de que a punição estaria restrita aos deveres perfeitos ou negativos, de forma a se poder retribuir o mal causado pelo ofensor se ele realizar uma ação intencional que gera danos aos outros, isto é, que retira os direitos dos agentes de uma comunidade, tais como a vida, a propriedade, a liberdade. Por mais que se possa censurar ações egoístas e viciosas, elas não serão passíveis de punição, o que parece garantir a liberdade dos agentes, sua autonomia. Em contraste com as outras virtudes, a justiça tem claramente uma valência negativa. Para Smith:

A mera justiça é, na maior parte das ocasiões, uma virtude negativa, pois apenas nos impede de ferir nosso vizinho. O homem que tão somente se abstém de violar a pessoa, a propriedade ou a reputação de seus vizinhos certamente tem muito pouco mérito positivo. Cumpre, no entanto, todas as regras do que é peculiarmente chamado justiça, e faz tudo o que seus iguais podem com conveniência forçá-lo a fazer, ou que o podem punir por 
não fazer. Frequentemente podemos cumprir todas as regras da justiça sentando-nos quietos, não fazendo nada (TMS, II.ii.1.9). ${ }^{20}$

Veja-se que a base da punição, então, se daria pela culpa de um agente em não ter seguido as regras da justiça, isto é, ter violado algum direito de alguém intencionalmente. É apenas essa violação que pode ser tomada como um erro. E isso é importante porque a punição legal implica um ato estatal intencional reprobatório e retributivo de causar dano a quem age erradamente, isto é, ao ofensor. Nessa concepção, o erro que será a base da punição se constituirá apenas pela moralidade pública, não sendo o erro privado uma razão suficiente para a punição, como é o caso no moralismo jurídico. Para Smith, o que faz algo ser errado, então, seria aquilo que seria reprovado pelo espectador imparcial em razão do ressentimento sofrido pela vítima (TMS, II.i.14), bem como o que se tomaria como "injúrias que provocam ressentimento por envolver a violação de outro direito" ( $L J(A)$, i.9). ${ }^{21}$

Identificada esta característica geral da teoria da punição de Smith, o próximo passo é saber se ela deve ser classificada como retributivista, uma vez que a mesma defende claramente que a justificação da punição a ser infligida ao ofensor se daria pela concordância do espectador imparcial em razão do ressentimento do ofendido (TMS, II.i.1-3). Contrariando a interpretação já canônica, como representada por Haakonssen, Miller,

20 TMS, II.ii.1.9: Mere justice, is upon most occasions, but a negative virtue, and only hinders us from hurting our neighbour. The man who barely abstain from violating either the person, or the estate, or the reputation of his neighbours, has surely very little positive merit. He fulfils, however, all the rules of what is peculiarly called justice, and does everything which his equals can with propriety force him to do, or which they can punish him for not doing. We may often fulfil all the rules of justice by sitting still and doing nothing.

${ }_{21}$ Nas LJ, Smith parece reformular sua teoria da justiça, substituindo a base emocional do espectador imparcial que envolveria ressentimento para desaprovação e punição das ações, como defendido em TMS, por uma noção mais clara de direitos. $\operatorname{Em} L J(A)$, i.9, ele diz: "Justice is violated whenever one is deprived of what he had a right to and could justly demand from others, or rather, when we do him any injury or hurt without a cause". Sobre essa mudança na teoria da justiça de Smith e de como isso parece implicar uma posição claramente antiutilitarista, ver o importante artigo de LIEBERMAN, 2006, p. 221-223. 
Russell e Salter, entre outros, não tomarei a teoria da punição de Adam Smith como puramente retributivista. Antes, irei interpretá-la como uma teoria híbrida da justificação da punição, que faz uso de aspectos retributivista, preventivista, expressivista e reabilitacionista de forma coerente. ${ }^{22}$

A base retributivista da punição já aparece no início do capítulo 1 (e seguintes) da primeira seção da Parte II da TMS, que trata do "Do mérito e demérito; ou dos objetos de recompensa e punição". Aqui Smith identifica claramente que o ressentimento provocado no espectador imparcial é a base do merecimento da punição. Dessa forma, a punição se justificaria pela retribuição do dano que é merecido por quem age erradamente e gera efeitos danosos. Smith diz: "Punir é, também, recompensar, remunerar, ainda que de maneira diferente: é devolver o mal pelo mal que se fez" (TMS, II.i.1.4). ${ }^{23}$ Esta base retributivista tem por fundamento o mérito do agente, isto é, o seu demérito. Isso porque o mérito é critério que serve para desaprovar uma ação, o que implica considerar o erro da ação e seus efeitos danosos. O ressentimento provocado no espectador imparcial seria a base do merecimento da punição, retribuindo ao ofensor o dano sofrido pela vítima. O papel do observador imparcial, então, seria garantir o objeto apropriado de ressentimento. Apela para uma empatia que se sente para com o imaginado ressentimento das vítimas e é o que parece garantir a aprovação da lei da retaliação (TMS, II.i.2.5). ${ }^{24}$

\footnotetext{
22 Todos esses comentadores referidos acima interpretam que Adam Smith faz uso de um modelo retributivista de punição, uma vez que o sentimento moral de ressentimento será a base normativa da justificação da pena ao ofensor. A punição, assim, seria uma forma de retribuição do ressentimento causado à vítima, e que é aplicado pelo espectador imparcial. Ver HAAKONSSEN, 1989, p. 116; MILLER, 1996, p. 196; RUSSELL, 1995, p. 143; SALTER, 1999, p. 207. Contrapondo a interpretação canônica, Thom Brooks defende algo similar ao argumento deste artigo, a saber, que Smith defende uma teoria unificada da punição, em que se pode identificar, para além do aspecto retributivista já conhecido, características tanto preventivista como reabilitacionista. Ver BROOKS, 2012a, p. 281. Defendo, em acréscimo, um aspecto expressivista na concepção de Smith.

${ }^{23}$ TMS, II.i.1.4: To punish, too, is to recompense, to remunerate, though in a different manner; it is to return evil for evil that has been done.

24 Nas LJ, Smith faz a mesma consideração sobre a medida da punição a partir do ressentimento imaginado pelo espectador imparcial. Em suas palavras: Now in all cases the measure
} 
O problema é que para além dessa concepção claramente retributivista, Smith também apela tanto para um argumento corretivista (reabilitacionista) quanto para um argumento preventivista (consequencialista). Ainda no capítulo 1 da primeira seção da Parte II da TMS, Smith diz que:

Ele deve arrepender-se e desculpar-se pela ação particular, que, em razão do medo da punição, ficará aterrorizado em ser culpado de uma ofensa similar. A satisfação natural dessa paixão tende automaticamente a produzir todas as finalidades políticas da punição: a correção do criminoso e o exemplo para o público (TMS, II.i.1.6). ${ }^{25}$

A citação claramente mostra que a punição também deve servir para gerar arrependimento no agente que age erradamente e gera efeitos danosos, de forma que o ofensor possa se arrepender, isto é, se sentir culpado e lamentar pelo erro cometido, possibilitando a sua regeneração. Ela também revela uma clara base preventivista, uma vez que a punição deve garantir, por medo de receber castigo semelhante, que outros não queiram repetir o ato danoso, tendendo a gerar o exemplo para o público, o que parece possibilitar o bem-estar social ou eficácia social. Assim, além de uma base retributivista, a punição estaria sendo justificada com argumentos corretivista e preventivista. No entanto, o que isto pode significar? ${ }^{26}$

of punishment to be inflected on the delinquent is the concurrence of the impartial spectator with the resentment of the injured (LJ(A), ii.89).

25 TMS, II.i.1.6: He must be made to repent and be sorry for this very action, that others, through fear of the like punishment, may be terrified from being guilty of the like offense. The natural gratification of this passion tends, of its own accord, to produce all the political ends of punishment; the correction of the criminal, and the example to the public.

${ }_{26}$ Robert Shaver defende que a teoria da punição de Smith toma a prevenção como um papel secundário. Diz que a justificação da punição que Smith oferece na TMS consiste na aprovação do espectador imparcial ao invés de apelar para a utilidade, que apenas pode confirmar juízos de conveniência e mérito, impedindo que se puna o inocente. Mas, como apela para este importante aspecto consequencialista, não poderia ser tomado como um retributivista puro. Ver SHAVER, 2006, p. 194-203. 
Creio que uma possível interpretação para solucionar essa aparente contradição na concepção de justiça retributiva de Smith, seja identificar que quando se fala na justificação da punição de fato se considera três coisas distintas, a saber, a justificação (i) da instituição da punição, (ii) do ato particular punitivo e (iii) das penalidades mesmas.

Com essa distinção em mãos, pode-se estipular que o que servirá como justificação da instituição da punição não será o mesmo que justificará o ato particular punitivo e nem as penalidades propriamente ditas. Por exemplo, o que parece justificar a quantidade das penas para Smith é a intenção da ação e não as suas consequências. Se os motivos da ação não forem errados, não se teria empatia pelo ressentimento do ofendido apenas por uma consequência danosa. Para Smith:

\begin{abstract}
Antes de podermos adotar o ressentimento do sofredor, devemos desaprovar os motivos do agente, e perceber que nosso coração renuncia a toda a empatia para com os afetos que influenciam sua conduta. Se estes não parecem inadequados, por mais funesta que sejam as consequências, a ação em si mesma não parece merecer nenhuma punição, ou ser objeto próprio de algum ressentimento (TMS, II.i.4.3). ${ }^{27}$
\end{abstract}

Isso parece implicar um critério deontológico, de forma a considerar a culpa do agente, sua mens rea, o critério central para a atribuição da quantidade da penalidade. Por exemplo, um assassinato desumano geraria ressentimento no espectador imparcial muito mais pelos maus motivos do ofensor do que pelo resultado danoso. Dessa forma, a desaprovação à intenção do ofensor parece justificar a proporcionalidade do castigo (TMS, II.i.4.4).

No entanto, isso significaria que as consequências não teriam importância na teoria da punição de Smith? Não parece ser esse o caso,

\footnotetext{
27 TMS, II.i.4.3: Before we can adopt the resentment of the sufferer, we must disapprove of the motives of the agent, and feel that our heart renounces all sympathy with the affections which influenced his conduct. If there appears to have been no impropriety in these, how fatal soever the tendency of the action which proceeds from them to those against whom it is directed, it does not seem to deserve any punishment, or to be proper object of any resentment.
} 
uma vez que na segunda seção da Parte II da TMS o castigo será tomado como necessário para conservar a ordem social, havendo um senso de conveniência de forma a preservar a ordem pública. Smith parece usar um argumento adicional ao dizer que a prevalência universal das práticas de injustiça geraria desordem e confusão na sociedade. Em suas palavras: “Por essa razão, geralmente procuramos outros argumentos, e a primeira consideração que nos ocorre é a desordem e a confusão da sociedade que resultaria da prevalência universal daquelas práticas" (TMS, II.ii.3.8). ${ }^{28}$

Isso pode levar a uma consideração de que a prevenção ou a consequência de eficácia social seria uma forma adicional de justificar a instituição da punição. Essa ideia parece ser corroborada quando se encontra a afirmação de que a punição também seria justificada pelo interesse geral da sociedade (TMS, II.ii.3.11). Aqui Smith dá um interessante exemplo da sentinela que adormece em sua vigília. Considera que mesmo ele não tendo a intenção de adormecer, seu descuido poderia ter colocado em perigo todo o exército, o que poderia justificar até mesmo a pena de morte. Mesmo considerando excessivamente severa a punição, ela poderia ser tomada como justa e adequada para a conservação do grupo (TMS, Il.ii.3.11). ${ }^{29}$

Essa ideia de considerar a prevenção como um argumento adicional para justificar a instituição da punição parece fazer sentido, inclusive levando em conta que em um modelo retributivista puro ou tradicional a instituição punitiva se justificaria pelo sofrimento do agente com base em sua culpabilidade. Diferentemente de um retributivismo de tipo kantiano, Smith expressamente recusa que a punição tenha o objetivo de causar

\footnotetext{
${ }_{28}$ TMS, II.ii.3.8: Upon this account we generally cast about for other arguments, and the consideration which first occurs to us, is the disorder and confusion of society which would result from the universal prevalence of such practices.

29 Nas palavras de Smith: A centinel, for example, who falls asleep up his watch, suffers death by the laws of war, because such carelessness might endanger the whole army. This severity may, upon many occasions, appear necessary, and, for that reason, just and proper. When the preservation of an individual is inconsistent with the safety of a multitude, nothing can be more just than that the many should be preferred to the one (TMS, II.ii.3.11).
} 
dor ao infrator; antes, ela teria um papel comunicativo ou expressivista, além de um caráter claramente reabilitacionista. Em suas palavras:

Ao contrário, o objeto principal do ressentimento não é meramente fazer que nosso inimigo, por sua vez, sinta dor, mas fazê-lo consciente que sente dor por causa de sua conduta passada, fazê-lo arrepender-se dessa conduta, fazendo-o sentir que a pessoa a quem causou dano não merece ser tratada dessa maneira. (...) Restaurar-lhe um sentido mais justo do que é devido aos outros, fazê-lo consciente do que nos deve e do erro que cometeu em relação a nós, é geralmente o propósito central de nossa vingança, a qual é sempre imperfeita quando isso não é alcançado (TMS, II.iii.1.5).30

Essa citação parece deixar claro que a punição só poderia ser tomada como retributivista de forma negativa, uma vez que o sofrimento do ofensor não seria a justificação adequada da punição, embora a retribuição da emoção de ressentimento seja um importante critério para justificar a punição particular ao ofensor. Antes, o espectador imparcial, que imagina o ressentimento da vítima, deve deixar claro para o ofensor que o seu sofrimento é devido ao seu comportamento errado em não respeitar os direitos dos membros da comunidade moral e política, além de oportunizar que o agente se arrependa da conduta errônea e possa reformar o seu caráter. ${ }^{31}$ É importante constatar que em um modelo re-

30 TMS, II.iii.1.5: The object, on the contrary, which resentment is chiefly intent upon, is not so much to make our enemy feel pain in his turn, as to make him conscious that he feels it upon account of his past conduct, to make him repent of that conduct, and to make him sensible, that the person whom he injured did not deserve to be treated in that manner. (...) To bring him back to a more just sense of what is due to other people, to make him sensible of what he owes us, and of the wrong that he has done to us, is frequently the principal end proposed in our revenge, which is always imperfect when it cannot accomplish this.

31 A teoria expressivista defende que a punição tem a finalidade básica de expressar ao ofensor que ele agiu erroneamente, mostrando ao mundo que ele não tinha o direito de fazer o que fez, sendo um instrumento convencional para expressar atitudes de ressentimento e indignação, bem como juízos de desaprovação e reprovação. Assim, a punição seria definida como uma condenação simbólica pública que aplica um tratamento duro ao ofensor em razão de seu erro. Ver FEINBERG, 1970, p. 95-118. A teoria reabilitacionista, por sua vez, defende que a punição tem 
tributivista negativo, em que a culpa do agente só é central para justificar 0 ato particular punitivo, o aspecto preventivista parece essencial para a justificação da instituição punitiva, sobretudo em um modelo liberal. ${ }^{32}$

Como conclusão, pode-se argumentar que essa teoria seria melhor classificada como uma teoria mista de punição, de forma a levar em conta diversos aspectos normativos, e que isso parece trazer bons resultados, como o de levar em conta a eficácia social, olhando para frente corretamente, com a cláusula de só punir o culpado e proporcionalmente, o que parece garantir os direitos individuais. Além disso, o caráter expressivista da punição parece reconhecer uma fundamental perspectiva dos direitos dos cidadãos que devem ser respeitados, uma vez que um crime nada mais seria que tirar um direito de alguém. Por fim, o papel reabilitacionista da punição parece implicar uma clara posição de reconciliação, oportunizando que ofensor se arrependa da conduta errada, reforme o seu caráter, podendo alcançar a ressocialização.

\section{Justiça e direitos}

Observou-se na seção anterior que a concepção de justiça retributiva de Smith considera a punição como uma atitude reativa de reprovação em razão do ofensor não respeitar os direitos das vítimas. Nesta última seção do artigo, gostaria de detalhar um pouco mais o que se poderia considerar propriamente como direitos nesta teoria moral sentimentalista.

por objetivo central a reforma do caráter do ofensor, auxiliando em sua transição de criminoso para o de cidadão ressocializado. Ver HAMPTON, 1984, p. 212-222.

${ }^{2}$ Brooks defende que Smith faz uso de uma teoria da punição com caráter híbrido, em que tanto a retribuição, a prevenção e a reabilitação são tomadas em conjunto: "Para Smith, a punição é dada apenas aos que merecem e proporcionalmente. Esta é a característica retributivista. Além disso, a punição almeja reformar os criminosos fazendo deles penitentes. Esta é a característica reabilitacionista. Finalmente, a punição é tomada em ordem de dissuadir os membros do público das atividades criminosas. Esta é a característica preventivista" (BROOKS, 2012a, p. 287). Sobre a diferença entre retributivismo negativo e positivo, ver BROOKS, 2012b, p. 33-34 e sobre o preventivismo ver, também, BROOKS, 2012b, p. 35-50. 
Um primeiro critério apresentado na segunda seção da Parte II da TMS, intitulada de "Da Justiça e Beneficência", é o padrão liberal do "dano aos outros", o que parece distinguir claramente entre a moralidade pública e a moralidade privada. Veja-se que a punição não recai sob as virtudes positivas da beneficência, generosidade, amizade, em razão de sua ausência não gerar nenhum dano, o que significa que ela não poderia provocar ressentimento compartilhado das pessoas. Para Smith, a mera ausência de virtudes positivas, "embora possa nos decepcionar quanto ao bem que seria razoável esperar-se, não provoca (...) nenhum mal do qual tenhamos ocasião de nos defender" (TMS, II.ii.1.4). Assim, a punição estaria restrita à virtude negativa da justiça, que é o âmbito dos direitos perfeitos ou negativos, de forma que se deve retribuir o mal causado se o ofensor fizer uma ação intencional que gera danos, isto é, que retira os direitos dos agentes de determinada comunidade moral-política (TMS, II.ii.1.5).33

Com isso, estabelece-se uma clara distinção entre o âmbito da moralidade privada, que é a esfera da censura moral, âmbito do conselho e persuasão, bem como do elogio, e o âmbito da moralidade pública, que é a esfera da censura legal ou punição, isto é, o âmbito da coerção. Importante notar que a justiça obriga em razão dessa consideração em relação aos direitos dos membros da comunidade. Assim, parece implicar uma posição liberal de justiça, pois é possível censurar ações egoístas, mas não se pode puni-las. A punição estaria restrita às ações de ataque, roubo, assassinato, isto é, ações que causam dano aos agentes, o que remete a uma defesa dos direitos à vida, integridade, propriedade, entre outros. ${ }^{34}$

33 Em seu artigo "Adam Smith on Justice, Rights, and Law", David Liebermam considera que se as violações de justiça promovem uma reação moral mais forte, a conduta requer que a virtude da justiça seja diferenciada do resto da vida moral, pois, em contraste com as outras virtudes, a virtude da justiça tem claramente uma orientação negativa. Ver LIEBERMAN, 2006, p. 217. Ver, também, HAAKONSSEN, 2006, p. 6-9.

34 Nas LJ, Smith diz que a justiça é violada quando não se respeitam os direitos dos agentes tanto como homens, como membros da família ou como membros do Estado, causando algum dano sem nenhuma razão específica. Ver LJ(A), i.10-11. Nas palavras de Smith: "The injury done to one as a father could not affect him merely as man, nor could that which is done to him as a 
Mas, para além dessa importante marca liberal na forma de tratar a justiça, Smith também reconhece uma força normativa na sociedade, dizendo que se pode defender as virtudes positivas. A sociedade pode prescrever regras, proibindo as mútuas ofensas e também ordenando a conveniência recíproca. Diz que a censura moral só adquire força de lei pela vontade do legislador que seja judicioso. Para Smith:

Um superior pode, por vezes, com aprovação universal, obrigar os que estão sob a sua jurisdição a comportar-se a esse respeito com certo grau de conveniência recíproca. As leis de todas as nações civilizadas obrigam os pais a sustentar seus filhos, e os filhos a sustentar seus pais, e impõem aos homens vários outros deveres de beneficência. Ao magistrado civil é confiado o poder não apenas de conservar a paz pública, restringindo a injustiça, mas o de promover a prosperidade da população, estabelecendo boa disciplina e desencorajando toda sorte de vício e inconveniência; ele pode, portanto, prescrever regras, proibindo não apenas as mútuas ofensas entre os concidadãos, mas ordenando, em certo grau, ajudas recíprocas" (TMS, II.ii.1.8). ${ }^{35}$

Com isso já se pode identificar que o modelo liberal de justiça defendido por Smith não o impede de aceitar um papel prescritivo do legislador e do magistrado, de forma a ter por objetivo central não apenas conter a injustiça, proibindo e condenando as ofensas mútuas, mas, também, de promover a prosperidade da comunidade, obrigando certas ajudas recíprocas, de forma mitigada, é claro. Penso que isso já parece apontar

member of estate be competent to him as a man or member of a family, but intirely proceeds from his state as a citzen" (LJ(A), i.11).

35 TMS, II.ii.1.8: A superior may, indeed, sometimes, with universal approbation, oblige those under his jurisdiction to behave, in this respect, with a certain degree of propriety to one another. The laws of all civilized nations oblige parents to maintain their children, and children to maintain their parents, and impose upon men many other duties of beneficence. The civil magistrate is entrusted with the power not only of preserving the public peace by restraining injustice, but of promoting the prosperity of the commonwealth, by establishing good discipline, and by discouraging every sort of vice and impropriety; he may prescribe rules, therefore, which not only prohibit mutual injuries among fellow-citizens, but command mutual good offices to a certain degree. 
para uma teoria de justiça com características liberais e comunitaristas. Retornarei a isso nas considerações finais.

Importante notar que há certa ambiguidade no tratamento que Smith dá à justiça no âmbito dos direitos na TMS, e isso porque, para ele, todas as regras morais-políticas seriam artificiais; mas, em algumas passagens, ele parece reconhecer a existência de certos direitos naturais. Por exemplo, ainda no registro do espectador imparcial, reconhece o direito igual de todos de se defenderem das ofensas, como o de exigirem certo grau de punição para os que a causaram. Nas palavras de Smith:

Entre iguais, cada indivíduo é naturalmente e previamente a instituição do governo civil, visto como tendo tanto o direito a defender-se das ofensas, como o de exigir certo grau de punição para os que a causaram. Todo espectador generoso não apenas aprova sua conduta quando isso ocorre, mas partilha de tal maneira seus sentimentos que não raro deseja ajudá-lo (TMS, II.ii.1.7). ${ }^{36}$

Veja-se que o ponto aqui seria defender que anteriormente à própria criação do Estado, os indivíduos já teriam certos direitos naturais, como os direitos à vida, igualdade, liberdade, etc. Nesse contexto, Smith reconhece, também, que todos os homens teriam horror à fraude, perfídia e a toda injustiça, sentindo contentamento quando da punição desses atos. Mas, diferentemente, também pondera que a justiça seria necessária para garantir a subsistência da própria sociedade (TMS, II.ii.3.9).37

36 TMS, II.ii.1.7: Among equals each individual is naturally, and antecedent to the institution of civil government, regard as having a right both to defend himself from injuries, and to exact a certain degree of punishment for those which have been done to him. Every generous spectator not only approves of his conduct when he does this, but enters so far into his sentiments as often to be willing to assist him.

37 Nas LJ, Smith faz referência aos direitos naturais em várias passagens. Em uma delas, por exemplo, diz que o que o que se costuma chamar de direitos naturais não precisa ser explicado e está vinculado a uma ideia de proteção ao dano e à liberdade: "That a man has received an injury when he is wounded or hurt any way is evident to reason, without any explication; and the same may be said of the injury done one when his liberty is any way restraint'd; any one will at first perceive that there is an injury done in this case" (LJ(A), i.24). Ver, também, LJ(A), ii.42-45. 
Outro critério que parece ter importância decisiva para o que se constituirá como justiça para Smith na TMS será o fair play, isto é, o jogar limpo ou a equidade. Diz que não se deve causar dano aos outros, mesmo que seja para se prevenir da própria ruína, reduzindo o amor de si. Para Smith: "Mas embora a ruína de nosso próximo possa nos afetar bem menos do que um diminuto infortúnio nosso, não devemos arruiná-lo para prevenir esse pequeno infortúnio" (TMS, II.ii.2.1). O ponto central seria reconhecer que por mais que seja legítimo perseguir o autointeresse, uma vez que naturalmente o sujeito estaria mais concernido com os próprios interesses, a trapaça com o outro seria desaprovada pelo espectador imparcial. A regra da justiça, então, que parece estar sendo formulada seria a seguinte: É aceitável perseguir o autointeresse, desde que jogando limpo com os outros. Nas palavras de Smith:

Na corrida pela riqueza, honras e privilégios, poderá correr o mais que puder, tencionando cada nervo e cada músculo, para superar todos os seus competidores. Mas, se empurra ou derruba qualquer um deles, a indulgência do espectador acaba de todo. É uma violação do fair play (jogo limpo ou equidade) que ele não pode admitir (TMS, II.ii.2.1).38

Esse critério de fair play parece remeter a certas regras socialmente aprovadas que deveriam ser obedecidas pelos agentes para que o resultado de suas ações autointeressadas sejam consideradas justas. Por exemplo, que não se deve mentir, enganar ou fraudar. Inclusive, Smith faz referência às leis mais sagradas da justiça que protegeriam a vida e a integridade dos indivíduos, suas propriedades e posses, bem como seus direitos pessoais, isto é, o que lhes seria devido pelas promessas dos outros" (TMS, II.ii.2.2).39

\footnotetext{
${ }_{38}$ TMS, II.ii.2.1: In the race for wealth, and honours, and preferments he may run as hard as he can, and strain every nerve and muscle, in order to outstrip all his competitors. But if he should justle, or throw down any of them, the indulgence of the spectators is entirely at an end. It is a violation of fair play, which they cannot admit of.

39 Smith parece formular um tipo de taxionomia com os crimes que mereceriam maior punição em razão de gerarem maior ressentimento no espectador imparcial e isso por causar um mal
} 
Por fim, queria fazer referência à importância do critério de utilidade pública como fonte da justiça para a garantia da subsistência da sociedade. Para Smith, a justiça seria o pilar central que sustentaria todo o edifício social, inclusive como uma forma essencial de superar o gap empático, pois apesar das pessoas serem naturalmente solidárias, "os homens sentem muito pouco por outro com quem não tenham nenhuma particular ligação, se comparado ao que sentem por si mesmos" (TMS, II.ii.3.4). O ponto ressaltado por Smith é que nenhuma sociedade poderia sobreviver sem que as leis da justiça fossem razoavelmente cumpridas, e isso significando que nenhuma relação social poderia ocorrer se as pessoas não se abstiverem de ofender os outros. ${ }^{40}$ Para Smith:

Como a sociedade não pode subsistir a menos que as leis da justiça sejam razoavelmente observadas, como nenhum trato social pode ocorrer entre os homens que em geral não se abstenham de causar dano uns aos outros, a consideração dessa necessidade, pensou-se, constituiu o fundamento sob o qual aprovamos que as leis da justiça coagissem pela punição os que as violassem (TMS, II.ii.3.6).41

maior às vítimas. $\mathrm{O}$ assassinato seria o mais atroz dos crimes. Após, viria a violação da propriedade, roubo e assalto. Por fim, a quebra de contrato. E isso parece fornecer o padrão normativo intersubjetivo (social) para o estabelecimento dos direitos. Nas palavras de Smith: "The most sacred laws of justice, therefore, those whose violations seems to call loudest for vengeance and punishment, are the laws which guard the life and person of our neighbour; the next are those which guard his property and possession; and the last of all come those which guard what are called his personal rights, or what is due to him from the promises of others" (TMS, II.ii.2.2). Sobre direitos pessoais, ver, também, LJ(A), ii.1-19.

$40 \mathrm{Na}$ WN, Smith também irá considerar o dever de justiça como um tipo de dever de proteger, tanto quanto possível, cada membro da sociedade da opressão dos outros, ou o dever de estabelecer uma exata administração da justiça. Ver WN, IV.ix.51; V.i.b.1. Ver, também, a consideração de Lieberman a respeito de tomar a justiça como o pilar central da ordem social, uma vez que nenhuma sociedade poderia sobreviver sem garantir certos direitos aos agentes que lhes protegeria da violência (dano) dos outros. (Ver LIEBERMAN, 2006, p. 217-218).

${ }_{41}$ TMS, II.ii.3.6: As society cannot subsist unless the laws of justice are tolerably observed, as no social intercourse can take place among men who do not generally abstain from injuring one another; the consideration of this necessity, it has been thought, was the ground upon which we approved of the enforcement of laws of justice by the punishment of those who violated them. 
Note-se que essa concepção de regras de justiça para a garantia da estabilidade social assim como formulada por Smith parece estar ligada a um senso do que é devido aos outros. Na terceira seção da Parte II da TMS, que trata da sorte moral, chamada por ele de irregularidade dos sentimentos, Smith dá um interessante exemplo a respeito desse senso do que é devido aos semelhantes. Diz que uma pessoa que atirasse uma grande pedra por sobre um muro na direção de uma via pública, sem advertir os que poderiam estar passando por ali e sem pensar aonde ela provavelmente cairia, poderia ser punido, mesmo sem ter ferido ninguém. Essa ação negligente seria passível de severa punição em razão do ofensor parecer demonstrar um grande desprezo pela felicidade e segurança dos outros agentes. Para Smith:

Há verdadeira injustiça em sua conduta. Ele expõe caprichosamente seu vizinho a algo que nenhum homem sensato decidiria se expor e, evidentemente, falta-lhe o senso do que é devido aos semelhantes, o que é a base da justiça e da sociedade (TMS, II. lii.2.8). ${ }^{42}$

Assim, o que fundamentaria a vivência em sociedade seriam as regras de justiça que parecem remeter a certo senso moral-político a respeito dos deveres enquanto membros de uma dada comunidade, o que parece implicar um senso moral comunitário que identificaria claramente o que se deve uns aos outros. Por isso, até mesmo uma ação que não causasse um dano direto às pessoas, e nem manifestasse uma intenção má como a de matar alguém, seria passível de punição, o que parece vincular a justiça à estabilidade social. ${ }^{43}$

42 TMS, II. iii.2.8: There is real injustice in his conduct. He wantonly exposes his neighbour to what no man in his senses would chuse to expose himself, and evidently wants that sense of what is due to his fellow-creatures which is the basis of justice and society.

43 Interessante comentar sobre dois aspectos positivos em relação à sorte moral resultante ou a irregularidade dos sentimentos para Smith. Em primeiro lugar, ela parece restringir o escopo de nosso senso de mérito à esfera das consequências das ações. Se somente as intenções pudessem ser alvo de ressentimento, então elas teriam de ser punidas. Nessa situação, nenhum indivíduo estaria seguro da suspeita dos outros e a consequência seria que "cada tribunal se tornaria uma verdadeira inquisição" (TMS, II.iii.3.2). Em segundo lugar, ela parece nos enco- 


\section{Considerações finais}

Após a análise de algumas características centrais da teoria dos sentimentos morais de Adam Smith, como a capacidade empática de imaginação dos sentimentos morais como medida de conveniência dos motivos e ações dos agentes, além de investigação sobre a justificação da punição, bem como o estudo da justiça no âmbito dos direitos individuais, gostaria de concluir esse artigo defendendo a hipótese de considerar a teoria da justiça de Adam Smith como uma teoria liberal-comunitarista, e isso porque ela:

(i) faria uso tanto da linguagem das virtudes como dos direitos, uma vez que a justiça, por exemplo, seria tanto uma virtude moral (negativa), sendo tomada como a base da punição em razão das violações de justiça envolverem um dano aos agentes, como seria compreendida, também, em termos de direitos naturais e pessoais, como os direitos à vida, integridade, propriedade e liberdade. Aqui a virtude negativa da justiça seria equivalente aos deveres perfeitos (negativos) de respeito à vida, propriedade e cumprimento de contratos;

(ii) defenderia uma neutralidade ética estatal, não punindo o não exercício das virtudes positivas como a do autodomínio, da prudência e da benevolência, apenas punindo o que geraria dano aos agentes, e que não respeitaria o fair play, por exemplo; mas, por outro lado, apoiaria um papel prescritivo do Estado (do legislador e magistrado) no âmbito dos deveres imperfeitos ou virtudes positivas, inclusive, para promover a prosperidade da comunidade. Embora não se possa punir os que não exercitam as virtudes beneficentes, a sociedade pode expressar o modo preferencial do caráter de seus membros;

\footnotetext{
rajar a levar as consequências das ações a sério. Em particular, isso releva que apenas as boas intenções não seriam suficientes para assegurar a honra e a estima dos outros, isto é, para garantir a segurança jurídica como uma importante base da a estabilidade social. Sobre Smith e a solução do problema da sorte moral, ver RUSSELL, 1999, p. 41-43.
} 
(iii) incluiria, em sua teoria da punição, os aspectos retributivista, expressivista, preventivista e reabilitacionista, conectando harmonicamente a característica de responsabilização individual com base na culpa e na liberdade de escolha dos agentes com os aspectos comunitários de estabilidade social e ressocialização, o que parece implicar certa concepção de responsabilidade coletiva;

(iv) usaria um padrão normativo social que é intersubjetivo, como o que é conveniente para a sociedade, de forma a considerar os direitos vinculados com o que se deveria uns aos outros na própria comunidade; entretanto, respeitaria também o critério pessoal de mérito e demérito em relação às escolhas dos agentes, suas ações e, inclusive, as consequências dessas ações que geram danos aos outros;

(v) defenderia uma concepção inclusivista das virtudes, de forma a conectar as virtudes positivas do autodomínio, prudência e benevolência com a virtude negativa da justiça para garantir tanto a felicidade pessoal quanto a felicidade coletiva, integrando, coerentemente, os domínios da vida pessoal e social, conectando de forma harmônica as esferas psicológica, moral, política, jurídica e até econômica, o que parece reconciliar adequadamente a moralidade privada com a moralidade pública.

Dada a integralidade de um agente humano, que vive sua vida pessoal no interior mesmo de uma comunidade, sendo tanto uma pessoa moral quanto um agente político e econômico, por exemplo, não seria mais adequado e eficiente poder contar com uma teoria da justiça com as características apontadas acima, e isso para poder lidar mais adequadamente com os complexos problemas práticos contemporâneos? A resposta parece ser afirmativa, e a razão para tal seria a de que uma teoria deste tipo seria mais apta para conectar harmonicamente as dimensões privada e pública que se mostram como fundamentais tanto para garantir uma 
vida bem-sucedida quanto para alcançar a estabilidade social. E isso já seria razão suficiente para continuar investigando outros aspectos da teoria da justiça de Adam Smith. Por exemplo, que concepção de justiça distributiva se encontraria na WN? Haveria coerência ou não entre a justiça retributiva da TMS, a teoria dos direitos das $L J$ e a justiça distributiva da $W N$ ? Contudo, infelizmente, essas e outras questões similares ultrapassam o escopo desse artigo.

\section{Referências}

ANSCOMBE, G. E. M. Modern Moral Philosophy. In: CRISP, Roger; SLOTE, Michael (ed.). Virtue Ethics. New York: Oxford University Press, 1998. p. 26-44. BIANCHI, A. M.; SANTOS, A. T. L. Além do cânon: mão invisível, ordem natural e instituições. Estudos Econômicos, São Paulo, v. 37, n. 3, p. 635-662, 2007. https://doi.org/10.1590/s0101-41612007000300007

BROADIE, Alexandre. Sympathy and the Impartial Spectator. In: HAAKONSSEN, K. (ed.). The Cambridge Companion to Adam Smith. New York: Cambridge University Press, 2006. p. 158-188. https://doi.org/10.1017/ccol0521770599.007 BROOKS, Thom. Punishment and Moral Sentiments. The Review of Metaphysics, Washington, DC, v. 66, n. 2, p. 281-293, 2012 a.

BROOKS, Thom. Punishment. New York: Routledge, 2012b.

CERQUEIRA, Hugo da Gama. Adam Smith e seu contexto: o iluminismo escocês. Economia e Sociedade, Campinas, v. 26, p. 1-28, 2006.

CERQUEIRA . Sobre a Filosofia Moral de Adam Smith. Síntese, Revista de Filosofia, Belo Horizonte, v. 35, n. 111, p. 57-86, 2008. https://doi.org/10.20911/21769389v35n111p57-86/2008

DARWALL, Stephen. Empathy and Adam Smith on Exchange. In: DARWALL, $S$. The second-person standpoint: morality, respect, and accountability. Cambridge, Mass: Harvard University Press, 2009. p. 43-48. https://doi. org/10.1017/s0953820808003397

FEINBERG, Joel. Doing and Deserving: essays in the Theory of Responsibility. Princeton, New Jersey: Princeton University Press, 1970. https://doi. org/10.1017/s0012217300028250 
HAAKONSSEN, Knud. The Science of a Legislator: The Natural Jurisprudence of David Hume and Adam Smith. Cambridge: Cambridge University Press, 1989. https://doi.org/10.1017/s0953820800000625

HAAKONSSEN, Knud. Introduction: The Coherence of Smith `s Thought. In: HAAKONSSEN, K. (ed.). The Cambridge Companion to Adam Smith. New York: Cambridge University Press, 2006. p. 1-21. https://doi.org/10.1017/ ccolo521770599.001

HAMPTON, Jean. The Moral Education Theory of Punishment. Philosophy and Public Affairs, Hanover, PA, v. 13, p. 208-238, 1984.

LIEBERMAN, David. Adam Smith on Justice, Rights, and Law. In: HAAKONSSEN, K. (ed.). The Cambridge Companion to Adam Smith. New York: Cambridge University Press, 2006. p. 214-245. https://doi.org/10.1017/ccol0521770599.009

MILLER, Eric. Sympathetic Exchange: Adam Smith and Punishment. Ratio Juris, Oxford, UK, v. 9, n. 2, p. 182-197, 1996. https://doi.org/10.1111/j.1467-9337.1996. tboo236.x

RAPHAEL, D. D.; MACFIE, A. L. Introduction. In: SMITH, A. The Theory of Moral Sentiments. Edited by D. D. Raphael and A. L. Macfie. The Glasgow Edition of the Works and Correspondence of Adam Smith, v. 1. Oxford: Oxford University Press, 1976. p. 1-52. https://doi.org/10.1093/actrade/9780198281894.book.1

RUSSELL, Paul. Freedom and Moral Sentiment: Hume's way of Naturalizing Responsibility. Oxford: Oxford University Press, 1995. https://doi.org/10.1017/ $\underline{\text { so012217300047144 }}$

RUSSELL, Paul. Smith on Moral Sentiment and Moral Luck. History of Philosophy Quarterly, Champaign, IL, v. 16, n. 1, p. 37-58, 1999.

SALTER, John. Sympathy with the Poor: Theories of Punishment in Hugo Grotius and Adam Smith. History of Political Thought, Exeter, UK, v. 20, n. 1, p. 205-224, 1999.

SHAVER, Robert. Virtues, Utility, and Rules. In: HAAKONSSEN, K. (ed.). The Cambridge Companion to Adam Smith. New York: Cambridge University Press, 2006. p. 189-213. https://doi.org/10.1017/ccol0521770599.008

SMITH, Adam. An Inquiry into the Nature and Causes of the Wealth of Nations. V. I and II. Edited by R. H. Campbell and A. S. Skinner; textual editor W. B. Todd. The Glasgow Edition of the Works and Correspondence of Adam Smith. Oxford: Oxford University Press, 1976. v. 2. https://doi.org/10.1017/ s0018246x0001709x 
SMITH, Adam. Lectures on Jurisprudence. Edited by R. L. Meek, D. D. Raphael, and P. G. Stein. The Glasgow Edition of the Works and Correspondence of Adam Smith. Oxford: Oxford University Press, 1978. v. 5. https://doi.org/10.1093/ oseo/instance.00042877

SMITH, Adam. The Theory of Moral Sentiments. Edited by D. D. Raphael and A. L. Macfie. The Glasgow Edition of the Works and Correspondence of Adam Smith. Oxford: Oxford University Press, 1976. v. 1. https://doi.org/10.1093/ actrade/9780198281894.book.1

STRAWSON, Peter. Freedom and Resentment. In: STRAWSON, P. Freedom and Resentment and Other Essays. London: Routledge, 2008. p. 1-28. https:// doi.org/10.4324/9780203882566 